\title{
UPAYA MENINGKATKAN KREATIVITAS MEMBENTUK BALOK BANGUNAN MELALUI METODE PRAKTIK LANGSUNG PADA ANAK
}

\author{
Rukiyati \\ TK Negeri Kabupaten Temanggung \\ Email : buyatinetata@gmail.com
}

\begin{abstract}
Abstrak
Tujuan dari penelitian ini adalah untuk mengetahui bahwa melalui metode praktik langsung dapat meningkatkan kreativitas dalam membentuk balok bangunan pada anak, 2) untuk mengetahui besarnya peningkatan kreativitas dalam membentuk balok bangunan melalui metode praktik langsung pada anak Kelompok A TK Negeri Kabupaten Temanggung Semester I Tahun Pelajaran 2016/2017.

Subyek penelitian ini adalah peserta didik Kelompok A TK Negeri Kabupaten Temanggung berjumlah 15 anak. Metode pengumpulan data yang digunakan adalah observasi, wawancara, dan dokumentasi. Kesimpulan dari penelitian ini adalah bermain balok bangunan terbukti efektif dapat meningkatkan kreativitas anak di Kelompok A TK Negeri Kabupaten Temanggung Tahun Pelajaran 2016/2017. Hal tersebut ditandai dengan tercapainya kriteria ketuntasan pada penelitian tindakan kelas yang sudah dilakukan. Ketuntasan hasil belajar anak yang mendapat nilai berkembang sangat baik dari Siklus I ke Siklus II mengalami kenaikan sebesar 60\%, sehingga dari kondisi awal ke Siklus II mengalami kenaikan sebesar 73,3\%. Pada indikator kinerja peneliti menentukan $80 \%$ anak dapat menunjukkan kreativitasnya, pada Siklus II telah melebihi target yang diharapkan yaitu 86,7\% anak mampu menunjukkan kreativitasnya dalam menciptakan suatu bentuk dengan menggunakan balok bangunan dan menceritakan hasil karyanya.
\end{abstract}

Kata Kunci : kreativitas, balok bangunan, metode praktik langsung

Abstract
The purpose of this study was to find out that through direct practice methods can increase creativity in building building blocks for children, 2) to determine the magnitude of increase in creativity in building building blocks through direct practice methods in children A Group of Temanggung District TK TK Semester I of 2016 Academic Year / 2017.The subjects of this study were 15 students in Group A of Temanggung Regency State Kindergarten. Data collection methods used are observation, interviews, and documentation. The conclusion of this study is that playing building blocks proved to be effective in increasing the creativity of children in Group A of Temanggung Regency State Kindergarten in 2016/2017 Academic Year. This is indicated by the achievement of completeness criteria in classroom action research that has been carried out. The completeness of the learning outcomes of children who get very well developed scores from Cycle I to Cycle II has increased by $60 \%$, so that from the initial conditions to Cycle II it increased by $73.3 \%$. In the research performance indicators determine $80 \%$ of children can show their creativity, in Cycle II has exceeded the expected target of $86.7 \%$ of children able to show their creativity in creating a form using building blocks and telling the results of their work.

Keywords: creativity, building blocks, direct practice methods

http://jurnal.upmk.ac.id/index.php/pelitapaud 


\section{PENDAHULUAN}

Anak usia dini memiliki kemampuan belajar yang luar biasa khususnya pada masa awal kanak-kanak. Keinginan anak untuk belajar menjadikan anak aktif dan eksploratif. Anak belajar dengan seluruh panca inderanya untuk memahami sesuatu dan dalam waktu singkat anak beralih ke hal lain untuk dipelajari. Masa kanakkanak merupakan masa paling penting karena merupakan pembentukan fondasi kepribadian yang menentukan pengalaman anak selanjutnya. Karakteristik anak usia dini menjadi mutlak dipahami untuk memiliki generasi yang mampu mengembangkan diri secara optimal. Dalam konteks pengembangan kreativitas, periode usia dini merupakan masa yang sangat kritis sehingga campur tangan pendidik mutlak diperlukan. Anak kreatif memuaskan rasa keingintahuannya melalui berbagai cara seperti bereksplorasi, berpraktik langsung, dan banyak mengajukan pertanyaan kepada orang lain. Suratno (2005 : 19) menjelaskan bahwa anak kreatif dan cerdas tidak terbentuk dengan sendirinya, tetapi memerlukan pengarahan, salah satunya dengan memberikan kegiatan yang dapat mengembangkan kreativitas anak.

Salah satu aspek perkembangan anak usia dini yang perlu dikembangkan adalah motorik halus. Pengembangan motorik halus anak dilakukan melalui olah tangan dengan menggunakan alat atau media kreatif seperti pensil, kertas, gunting, plastisin, balok dan lain sebagainya. Dengan menggunakan media kreatif anak dapat melaksanakan kegiatan yang melatih otot-otot tangan dan koordinasi mata, pikiran dengan tangannya. Keterampilan yang dapat dikembangkan yaitu keterampilan tangan, baik dengan menggunakan salah satu tangan atau menggunakan kedua tangan, contohnya adalah kegiatan membentuk. Kegiatan ini dapat menunbuhkan kecakapan hidup dan melatih rasa keindahan.

Anak usia Taman Kanak-kanak merupakan tahap usia anak yang berada pada tahap bermain konstruktif, yang ditandai dengan aktivitas anak yang senang membuat aneka bangunan dengan berbagai macam benda. Keterampilan membentuk salah satunya dapat dilakukan menggunakan balok. Dalam meningkatkan kreativitas anak dalam membentuk balok bangunan pada anak-anak dapat dilakukan dengan berbagai hal, salah satunya dengan menggunakan metode praktik langsung. Pembelajaran dengan metode praktik langsung akan memberikan kesempatan kepada anak untuk melihat, merasakan, 
bereksplorasi secara langsung dengan media yang digunakan.

Kenyataan yang terjadi di TK Negeri Kabupaten Temanggung khususnya Kelompok A dari hasil observasi dapat diketahui bahwa kreativitas anak dalam membentuk suatu benda masih rendah, anak masih kebingungan dalam membentuk sebuah bangunan, misalnya bentuk rumah, bentuk mobil atau bentuk lainnya, selain itu anak-anak tidak semangat dalam belajar. Ini dibuktikan dengan hasil pekerjaan anak dari 15 anak hanya 2 anak yang sudah mampu membentuk sebuah bangunan dengan balok bangunan, sebagian lainnya masih perlu bimbingan dari guru.

Rendahnya kreativitas membentuk balok bangunan pada anak Kelompok A di TK Negeri Kabupaten Temanggung disebabkan oleh beberapa penyebab yaitu, penggunaan media pembelajaran yang digunakan terbatas, guru hanya menggunakan gambar macam-macam bentuk bangunan, akibatnya kreativitas anak dalam membentuk balok bangunan belum terkuasai dengan baik. Anak-anak masih kebingungan saat menyusun balokbalok menjadi sebuah bentuk bangunan. Penyajian dalam metode pembelajaran yang digunakan adalah ceramah, guru hanya bercerita di depan menerangkan gambar sebuah bangunan, akibatnya saat kegiatan belajar mengajar berlangsung kurang kondusif, banyak anak yang bercerita dengan teman, dan ada yang bermain sendiri, akibatnya proses kegiatan belajar mengajar kurang maksimal. Kegiatan untuk meningkatkan kreativitas anak dengan permainan tidak pernah dilakukan. Guru hanya mengulang-ulang kegiatan pembelajarannya dengan mengerjakan LKA tanpa diselingi dengan kegiatan bermain. Media pembelajaran pada tingkat TK sangat diperlukan saat mengajar, karena dunia anak merupakan dunia bermain, maka dari itu pembelajaran yang ada di TK seharusnya diarahkan dengan cara bermain sambil belajar yang dikemas dengan menarik.

\section{METODE PENELITIAN}

Jenis Penelitian

Penelitian ini menggunakan penelitian tindakan kelas atau PTK, berkolaborasi dengan guru untuk menilai kemampuan dan perkembangan anak.

\section{Tempat Penelitian}

Lokasi penelitian tindakan kelas ini dilakukan di TK Negeri Pembina Kabupaten Temanggung.

\section{Waktu Penelitian}

Penelitian dilaksanakan pada Semester I tahun pelajaran 2016/2017, 
tepatnya pada bulan Oktober sampai dengan Desember 2016.

\section{Subjek Penelitian}

Subjek penelitian adalah peserta didik Kelompok A TK Negeri Kabupaten Temanggung yang berjumlah 15 anak, terdiri dari 6 anak laki-laki dan 9 anak perempuan dengan melibatkan satu orang guru sebagai observer.

\section{Sumber Data}

Sumber data dibedakan atas data primer dan Sumber data dibedakan atas data primer dan data sekunder. Sumber data primer adalah objek yang diobservasi langsung di lapangan dan para informan atau pemberi informasi yang diwawancarai. Dalam penelitian ini yang bertindak sebagai sumber data primer adalah anak Kelompok A sejumlah 15 anak dan seorang guru TK Negeri Kabupaten Temanggung. Sumber data sekunder berupa dokumentasi dan arsiparsip resmi yang dapat mendukung hasil penelitian yaitu hasil raport, daftar penilaian, dan daftar hadir anak.

\section{Teknik dan Alat Pengumpulan Data}

Observasi

Observasi merupakan teknik mengumpulkan data dengan cara mengamati setiap kejadian yang sedang berlangsung dan mencatatnya dengan alat observasi tentang hal-hal yang akan diamati dan diteliti (Wina Sanjaya, 2011: 86). Observasi atau pengamatan dilakukan di Kelompok A TK Negeri Kabupaten Temanggung untuk mengetahui peningkatan kreativitas dalam membentuk balok bangunan melalui metode praktik langsung. Pengamatan ini dilakukan dengan menggunakan lembar observasi check list yang telah disiapkan dengan memberikan skor jika hal yang diamati muncul. Menurut Wina Sanjaya (2011:93), check list merupakan pedoman observasi yang berisikan daftar dari semua aspek yang akan diobservasi, sehingga observer tinggal memberi tanda cek $(\sqrt{ })$ mengenai aspek yang akan diamati.

Dokumentasi

Dokumentasi merupakan catatan suatu peristiwa yang sudah terjadi yang berupa tulisan, gambar-gambar atau video yang direkam oleh seseorang dan digunakan sebagai data sebagai hasil pengamatan. Metode dokumentasi dalam penelitian ini berupa foto-foto hasil kerja anak yang dapat menggambarkan mengenai kreativitas dalam membentuk balok bangunan melalui metode praktik langsung. Dokumentasi tersebut berbentuk daftar penilaian. Dokumentasi dilakukan saat observasi, pengambilan foto-foto tersebut bertujuan agar data yang diperoleh yakni yang berupa fakta-fakta peristiwa 
proses pembelajaran dapat optimal, sehingga dapat dijadikan sebagai bukti, selain itu dapat dijadikan sebagai bahan evaluasi terhadap perkembangan kognitif anak.

Wawancara

$$
\text { Wawancara adalah metode }
$$
pengumpulan data dengan jalan bertanya untuk mendapatkan informasi dengan cara bertanya secara langsung kepada responden. Sebelum melakukan wawancara, peneliti membuat daftar pertanyaan untuk memperoleh data tentang keadaan TK Negeri Kabupaten Temanggung, baik kondisi TK maupun anak didiknya, dalam penelitian ini peneliti mengadakan wawancara dengan guru dan kepala sekolah. Dari hasil wawancara ini dapat diketahui respon anak terhadap pembelajaran dan kesulitan-kesulitan yang dihadapi dalam meningkatkan kreativitas dalam membentuk balok bangunan.

\section{Analisa Data}

Dalam analisis data ini dilakukan perbandingan antara Siklus I dan Siklus II, maka analisis data ini menggunakan deskriptif komparatif, yaitu mendeskripsikan kondisi lapangan yang dapat dilihat pada gambaran obyek penelitian yang telah diperoleh dengan tujuan untuk mengetahui peningkatan kreativitas dalam membentuk balok bangunan. Kemudian data tersebut dikomparasikan dengan tinjauan pustaka sebagai tolok ukur penelitian sehingga dapat diambil kesimpulan.

Kreativitas dalam membentuk balok bangunan pada anak diukur dengan menggunakan analisis kualitatif yang merupakan bentuk angka dengan rumus sebagai berikut :

$$
P=\frac{F}{N} \times 100 \%
$$

\section{Keterangan :}

$\mathrm{P}$ : prosentase yang diharapkan

$\mathrm{F}$ : hasil yang dicapai anak

$\mathrm{N}$ : jumlah anak keseluruhan

\section{Indikator Keberhasilan}

Perumusan indikator digunakan sebagai tolok ukur keberhasilan penelitian yang dilakukan. Indikator kinerja merupakan rumusan kinerja yang akan dijadikan acuan dalam menentukan keberhasilan atau keefektifan penelitian (Sawarji Suwandi, 2010: 61). Indikator keberhasilan dalam penelitian ini mengenai kreativitas dalam membentuk balok bangunan pada anak di Kelompok A TK Negeri Kabupaten Temanggung melalui metode praktik langsung akan terlihat dari proses pembelajaran yang sesuai dengan indikator keberhasilan yang telah ditetapkan.

Indikator keberhasilan dalam penelitian ini adalah ditandai dengan meningkatnya kreativitas dalam 
membentuk balok bangunan pada anak. Peneliti menentukan indikator keberhasilan yaitu dengan persentase rata-rata $80 \%$ anak mampu membentuk balok bangunan.

\section{Tabel 1. Indikator Keberhasilan Anak}

\begin{tabular}{|c|c|c|c|c|c|}
\hline $\mathrm{N}$ & \multicolumn{2}{|l|}{ Indikator } & \multicolumn{3}{|c|}{ Penilaian } \\
\hline o & & & B & $\mathrm{BS}$ & BS \\
\hline 1 & $\begin{array}{l}\text { Anak } \\
\text { menciptakan } \\
\text { dengan } \\
\text { bangunan }\end{array}$ & $\begin{array}{r}\text { mampu } \\
\text { bentuk } \\
\text { balok }\end{array}$ & & & \\
\hline 2 & $\begin{array}{l}\text { Anak } \\
\text { menceritakan } \\
\text { balok bangunan } \\
\text { dibuatnya }\end{array}$ & $\begin{array}{l}\text { mampu } \\
\text { bentuk } \\
\text { in yang }\end{array}$ & & & \\
\hline
\end{tabular}

Keterangan :

BB : Belum Berkembang

BSH : Berkembang Sesuai Harapan

BSB : Berkembang Sangat Baik

\section{Prosedur Penelitian}

\section{Siklus I}

Perencanaan

Upaya dalam merencanakan langkah-langkah sebelum memulai tindakan penelitian merupakan tahap awal perencanaan penelitian. Peneliti menyusun rencana kegiatan harian (RKH). Pelaksanaan perencanaan penelitian ini kegiatannya yaitu mengkoordinasikan terlebih dahulu tentang kegiatan pembelajaran yang akan dilaksanakan oleh peneliti dan guru kelas Kelompok A. Koordinasi pembelajaran yang dilakukan yaitu sebelumnya menentukan tema dan sub tema pembelajaran, dilanjutkan memilih indikator dan merumuskannya ke dalam RKH.

Media yang digunakan dalam penelitian ini menggunakan balok bangunan yang terbuat dari kayu yang cukup ringan, sehingga aman digunakan untuk anak. Kemudian anak menghubungkan bentuk balok bangunan dengan benda yang ada di sekitarnya dengan mengerjakan LKA, setelah itu anak membentuk balok bangunan menjadi suatu benda, menggambar suatu bangunan dan menceritakan bentuk bangunan yang dibuatnya.

Dalam penelitian ini peneliti telah menyiapkan instrument pengamatan berupa hasil kreativitas membentuk balok bangunan pada setiap pelaksanaan. Hal tersebut digunakan untuk perbandingan kreativitas anak dalam membentuk balok bangunan dan menentukan keberhasilan pembelajaran. Kegiatan berikutnya yaitu penataan kelas yang dilakukan secara berkelompok.

Pelaksanaan tindakan

Pada pertemuan pertama kegiatan awal pembelajaran dengan melakukan gerakan fisik motorik ringan, peneliti mengucap salam, absensi, dan apersepsi menanyakan macam-macam bangunan yang ada di sekitar. Kegiatan inti dimulai dengan memberikan penjelasan mengenai 
tata cara metode praktik langsung menggunakan balok bangunan. Anak-anak dibagi menjadi 3 kelompok dan diberi tugas membentuk sebuah bangunan dari balok bangunan, menjawab pertanyaan peneliti dan mengerjakan LKA. Kegiatan diakhiri dengan diskusi tentang kegiatan yang telah dilakukan, pesan-pesan, berdoa sebelum pulang dan salam.

Pada pertemuan kedua, pembelajaran diawali dengan memasukkan bola dalam keranjang, kemudian dilanjutkan dengan salam, absensi dan apersepsi. Kegiatan inti, peneliti memberi tugas kepada anak untuk menyusun balok bangunan sesuai keinginan anak, tanya jawab dan mengerjakan LKA. Pembelajaran diakhiri dengan mengevaluasi pembelajaran yang telah dilaksanakan, nasehat, doa sebelum pulang dan salam.

Pertemuan ketiga, pada kegiatan awal pembelajaran peneliti mengucap salam, absensi, bernyanyi dan apersepsi tentang tempat pekerjaan. Kegiatan inti, peneliti mengingatkan kembali tentang aturan bermain balok bangunan, anak-anak bermain balok bangunan dan peneliti bertanya mengenai nama bangunan yang dibuat anak. Kegiatan akhir pembelajaran, peneliti mengevaluasi kegiatan pembelajaran yang telah dilaksanakan, tanya jawab, doa pulang dan salam.

\section{Observasi}

Observasi atau pengamatan merupakan proses mencermati jalannya pelaksanaan tindakan. Observasi dilakukan selama kegiatan berlangsung dengan menggunakan lembar observasi yang telah direncanakan. Tujuannya adalah untuk mengamati apakah ada peningkatan kreativitas dalam membentuk balok bangunan pada anak saat kegiatan praktik langsung berlangsung.

Refleksi

$$
\text { Refleksi merupakan langkah }
$$
mengingat kembali kegiatan yang sudah dilakukan. Lembar observasi yang telah diisi kemudian diolah dengan cara menganalisis dan mengevaluasi yang bertujuan untuk mengetahui apakah pada kegiatan tersebut ditemui kesulitankesulitan pada anak sehingga hasilnya belum optimal kemudian dikaji dan dikaitkan dengan teori-teori yang relevan untuk mendapatkan hasil yang optimal. Setelah mengkaji, menganalisis, dan mengevaluasi pada Siklus I peneliti menindaklanjutinya dengan melakukan penelitian di Siklus II.

\section{Siklus II}

Perencanaan

Mengidentifikasi dan merumuskan masalah yang terjadi pada Siklus I. 
Menyusun tindakan rencana pelaksanaan pembelajaran harian.

Tindakan

Pertemuan pertama, kegiatan awal dimulai dengan mengucap salam, berdoa, bernyanyi dan apersepsi mengenai sub tema yang akan dilaksanakan. Kegiatan inti, anak-anak dibagi menjadi 2 kelompok yaitu kelompok besar dan kelompok kecil. Kelompok besar mendapat tugas meronce dan kelompok kecil mendapat tugas bermain balok bangunan. Setelah kedua kelompok selesai, maka kedua kelompok tersebut bergantian dalam mengerjakan tugas. Kegiatan diakhiri dengan mengulas kegiatan sehari, tanya jawab, peneliti memberikan reward kepada anak yang mampu melaksanakan tugas dengan baik, berdoa sebelum pulang dan salam.

Pertemuan kedua diawali dengan mengucap salam, absensi, berdoa, bernyanyi dan apersepsi tentang kegiatan yang akan dilaksanakan. Peneliti membagi dua kelompok, ketika anak selesai melakukan kegiatan bermain balok bangunan atau selesai mengerjakan kegiatan menempel anak-anak bertukar tempat untuk mengerjakan tugas masingmasing. Kegiatan diakhiri dengan mengulas kegiatan sehari, tanya jawab, peneliti memberikan reward kepada anak yang mampu melaksanakan tugas dengan baik, berdoa sebelum pulang dan salam.

Kegiatan pada pertemuan ketiga masih sama seperti pertemuan sebelumnya, kelompok kecil mendapat tugas bermain balok bangunan, kelompok besar mendapat tugas menggambar dan mewarnai kemudian kedua kelompok tersebut bertukar kegiatan. Kegiatan diakhiri dengan mengulas kegiatan sehari, tanya jawab, peneliti memberikan reward kepada anak yang mampu melaksanakan tugas dengan baik, berdoa sebelum pulang dan salam.

Pengamatan

Kegiatan yang dilaksanakan pada tahap pengamatan adalah mengamati proses pembelajaran yang dipusatkan pada kegiatan anak, mencatat semua hasil yang dicapai anak selama pembelajaran.

Refleksi

Setelah pembelajaran berakhir, peneliti berdiskusi dengan teman sejawat untuk mengetahui kekurangan dan kelebihan dalam pembelajaran. Pada Siklus II ini perbaikan pembelajaran dapat berjalan sesuai dengan rencana yang telah ditetapkan dan telah mencapai indikator keberhasilan yang telah ditetapkan yaitu $80 \%$ anak sudah mampu menunjukkan kreativitasnya. 
HASIL PENELITIAN DAN

\section{PEMBAHASAN}

Kondisi Awal

Saat peneliti melakukan pengamatan pertama kali dan belum dilakukan kegiatan perbaikan pembelajaran, lebih dari sebagian jumlah anak kelompok A TK Negeri Kabupaten Temanggung mengalami kendala dalam kemampuan menyusun balok menjadi sebuah bangunan. Pada proses pembelajaran prasiklus, guru belum menemukan metode yang tepat dan efektif dalam kegiatan belajar mengajar, sehingga untuk pembelajaran kreativitas membentuk balok bangunan pada prasiklus dari 15 peserta anak didik, hanya 2 anak atau 13,3\% berkembang sangat baik, 2 anak atau 13,3\% berkembang sesuai harapan, dan 11 anak atau $73,4 \%$ belum berkembang. Hasil tersebut dapat dilihat pada tabel berikut :

Tabel 2 Kondisi Awal Sebelum Penelitian

\begin{tabular}{ccc}
\hline Penilaian & $\begin{array}{c}\text { Jumlah } \\
\text { Anak }\end{array}$ & Persentase \\
\hline BB & 2 & $13,3 \%$ \\
BSH & 2 & $13,3 \%$ \\
BSB & 11 & $73,4 \%$ \\
\hline
\end{tabular}

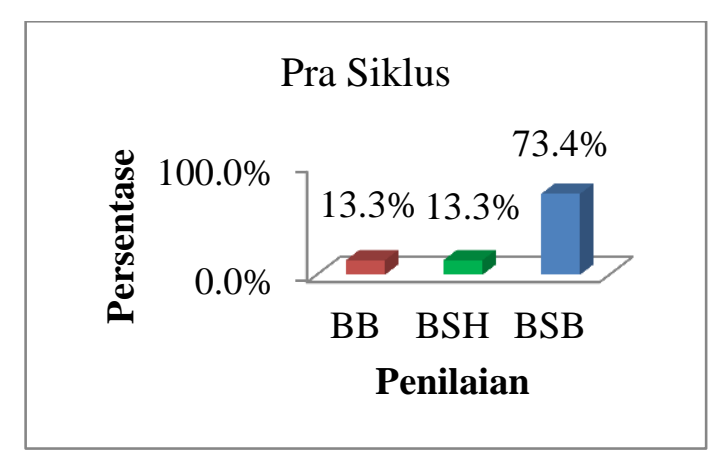

Grafik 1 Kondisi Awal Sebelum Penelitian

Keterangan :

BB : Belum Berkembang

BSH : Berkembang Sesuai Harapan

BSB : Berkembang Sangat Baik

Berdasarkan tabel dan grafik di atas dapat disimpulkan bahwa kreativitas menyusun balok bangunan anak kelompok A TK Negeri Kabupaten Temanggung masih rendah. Padahal yang diharapkan dalam kegiatan tersebut $80 \%$ anak berhasil atau anak dapat menunjukkan kreativitasnya dalam menyusun balok bangunan dengan baik. Hasil belajar sebelum tindakan perbaikan pembelajaran dijadikan tolak ukur atau landasan untuk melakukan perbaikan pembelajaran kreativitas menyusun balok bangunan pada anak Kelompok A TK Negeri Kabupaten Temanggung Semester I Tahun Pelajaran 2016/2017.

Siklus I

Setelah melakukan perencanaan dan pelaksanaan tahap selanjutnya dari penelitian tindakan kelas ini adalah observasi. Observasi dilakukan bersamaan 
dengan berlangsungnya tindakan yaitu ketika kegiatan praktik langsung menggunakan balok bangunan. Peningkatan kreativitas anak dapat diketahui dari kemampuan anak untuk menciptakan bentuk dengan balok bangunan dan kemampuan untuk menceritakan bentuk balok bangunan yang dibuatnya. Melalui panduan instrumen LKA dari pertemuan pertama sampai pertemuan ketiga dapat diketahui bahwa kreativitas anak mulai meningkat secara bertahap.

Pada pertemuan pertama sebagian besar anak belum memperhatikan penjelasan dari peneliti, anak asyik bermain sendiri, sehingga kemampuan anak dalam membentuk balok bangunan belum berkembang. Hasil observasi pertemuan pertama, belum ada peningkatan kreativitas anak dari pra siklus, hanya 2 atau $13,3 \%$ anak menunjukkan persentase berkembang sangat baik, 2 anak atau 13,3\% berkembang sesuai harapan, dan 11 atau $73,4 \%$ belum berkembang.

Pada pertemuan kedua Sikus I, peningkatan kreativitas anak dengan kriteria berkembang sangat baik berjumlah 3 anak atau $20 \%$ dari total anak, sedangkan anak dengan kriteria berkembang sesuai harapan 4 atau 26,7\%, dan anak yang

belum berkembang berjumlah 8 atau $53,3 \%$. Terjadi peningkatan dibanding pertemuan sebelumnya.

Dari hasil observasi pertemuan ketiga Siklus I terlihat jumlah anak yang menunjukkan kreativitas berkembang sangat baik berjumlah 4 atau $26,7 \%$, berkembang sesuai harapan 4 atau 26,7\%, dan anak dengan kriteria belum berkembang berjumlah 7 atau $46,6 \%$.

Berdasarkan hasil pengamatan dalam penelitian melalui praktik langsung menggunakan balok bangunan untuk meningkatkan kreativitas pada anak kelompok A TK Negeri Kabupaten Temanggung Siklus I, terlihat perkembangan sebagian anak sudah mampu menunjukkan kreativitasnya dengan membuat sebuah bangunan dari balok bangunan dan menceritakan hasil karyanya, walaupun belum semua anak berhasil melakukannya dengan baik. Tabel 3. Kreativitas Anak Siklus I

\begin{tabular}{ccccccc}
\hline $\begin{array}{c}\text { Penila } \\
\text { ian }\end{array}$ & \multicolumn{2}{c}{ Pertemuan I } & \multicolumn{2}{c}{ Pertemuan } & \multicolumn{2}{c}{ Pertemuan } \\
& Jml & $\%$ & Jml & $\%$ & Jml & $\%$ \\
& anak & & $\begin{array}{c}\text { III } \\
\text { ana }\end{array}$ & \multicolumn{3}{c}{$\begin{array}{c}\text { ana } \\
\mathrm{k}\end{array}$} \\
\hline BSB & 2 & 13,3 & 3 & $20 \%$ & 4 & 26, \\
& & $\%$ & & & & $7 \%$ \\
BSH & 3 & $20 \%$ & 4 & 26,7 & 4 & 26, \\
& & & & $\%$ & & $7 \%$ \\
BB & 10 & 66,7 & 8 & 53,3 & 7 & 46, \\
& & $\%$ & & $\%$ & & $6 \%$ \\
\hline
\end{tabular}




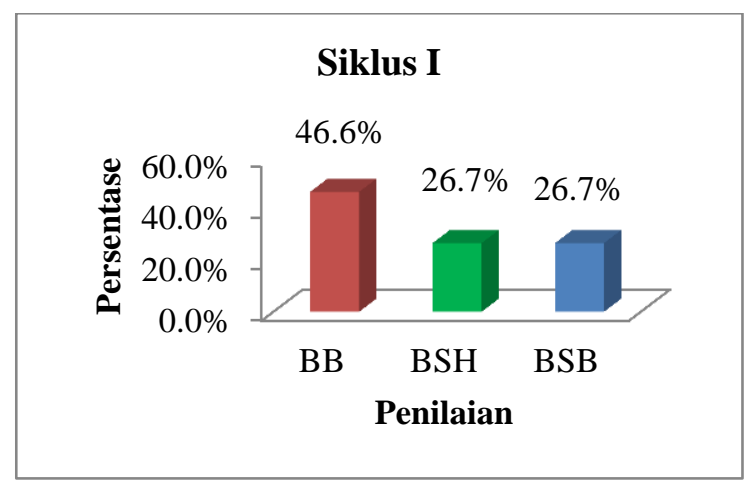

Grafik 2. Kreativitas Anak Siklus I

Dari hasil tersebut menunjukkan adanya peningkatan jumlah anak yang tuntas walaupun hasilnya belum optimal, pada kondisi awal tercatat hanya 13,3\% anak yang tuntas meningkat menjadi 26,7\% pada Siklus I.

Secara umum kelebihan-kelebihan yang terjadi dalam Siklus I adalah kegiatan pembelajaran berjalan lancar sesuai dengan rencana kegiatan yang telah ditentukan. Terjadi peningkatan kreativitas anak meskipun belum sesuai dengan indikator ketuntasan yang telah ditetapkan.

Berdasarkan hasil observasi yang diperoleh, beberapa hal yang menjadi kendala atau kelemahan dalam pelaksanaan perbaikan pembelajaran Siklus I antara lain:

Dalam bermain balok bangunan dilakukan secara bersama-sama setiap kelompok, sehingga guru kurang mengawasi permainan balok bangunan.

Ketika anak mengerjakan LKA setelah bermain balok bangunan, masih banyak anak yang mengalami kesulitan. Masih ada anak yang tidak mau mengerjakan tugas yang diberikan. Hasil peningkatan kreativitas anak belum tercapai dalam siklus ini karena anak yang tuntas baru mencapai $26,7 \%$.

Berdasarkan evaluasi tersebut peneliti dan teman sejawat bermusyawarah untuk memecahkan masalah yang terjadi dengan melanjutkan tindakan ke Siklus II. Karena berdasarkan nilai dan persentase yang diperoleh belum mencapai kriteria ketuntasan $80 \%$. Belum tercapainya indikator keberhasilan yang ditetapkan maka perlu dilaksanakannya Siklus II sebagai upaya untuk mencapai indikator keberhasilan yang ditentukan. Selain itu, perubahan setting kelas dan pembagian kelompok perlu ditinjau kembali. Pada hasil penelitian yang telah dilakukan terhadap permasalahan yang terdapat pada Kelompok A tentang kreativitas anak yang belum mencapai indikator keberhasilan yang ditetapkan, maka peneliti selanjutnya melakukan perbaikan pada siklus berikutnya dengan cara setting kelas diubah dengan menggunakan meja dan ada yang duduk di karpet. Pembagian kelompok diatur kembali yaitu pembagian kelompok besar dan kelompok kecil.

Siklus II 
Observasi dilakukan selama pembelajaran berlangsung pada Siklus II. Peneliti melihat dan mengamati perkembangan anak dengan hasil belajar yang telah dilaksanakan anak yaitu bermain balok bangunan untuk meningkatkan kreativitas anak.

Keadaan anak pada pertemuan pertama Siklus II menunjukkan adanya peningkatan kreativitas, anak yang berkategori berkembang sangat baik 6 atau $40 \%$, berkembang sesuai harapan 5 atau 33,3\% anak, belum berkembang 4 atau 26,7\% anak. Pada pertemuan kedua Siklus II menunjukkan bahwa anak yang sudah mampu sesuai dengan indikator berjumlah 9 anak yang berarti $60 \%$ dari seluruh anak, 4 anak atau 26,7\% dengan kategori berkembang sesuai harapan, dan anak yang masih belum berkembang 2 atau 13,3\%. Pada pertemuan ketiga Siklus II dapat dilihat bahwa anak yang sudah mampu sesuai dengan indikator berjumlah 13 anak yang berarti $86,7 \%$ dari seluruh anak, 2 anak atau $13,3 \%$ dengan kategori berkembang sesuai harapan.
Tabel 4. Kreativitas Anak Siklus II

\begin{tabular}{ccccccc}
\hline $\begin{array}{c}\text { Penil } \\
\text { aian }\end{array}$ & \multicolumn{2}{c}{ Pertemuan I } & \multicolumn{2}{c}{ Pertemuan II } & \multicolumn{2}{c}{ Pertemuan } \\
& & & & & \multicolumn{2}{c}{ III } \\
& Jm & $\%$ & Jml & $\%$ & Jml & $\%$ \\
& $\begin{array}{c}\text { ana } \\
\text { ana } \\
\mathrm{k}\end{array}$ & & k & & k & \\
& 6 & $40 \%$ & 9 & $60 \%$ & 13 & 86,7 \\
& & & & & & $\%$ \\
BSB & 5 & 33,3 & 4 & 26,7 & 2 & 13,3 \\
& & $\%$ & & $\%$ & & $\%$ \\
BB & 4 & 26,7 & 2 & 13,3 & 0 & $0 \%$ \\
& & $\%$ & & $\%$ & & \\
\hline
\end{tabular}

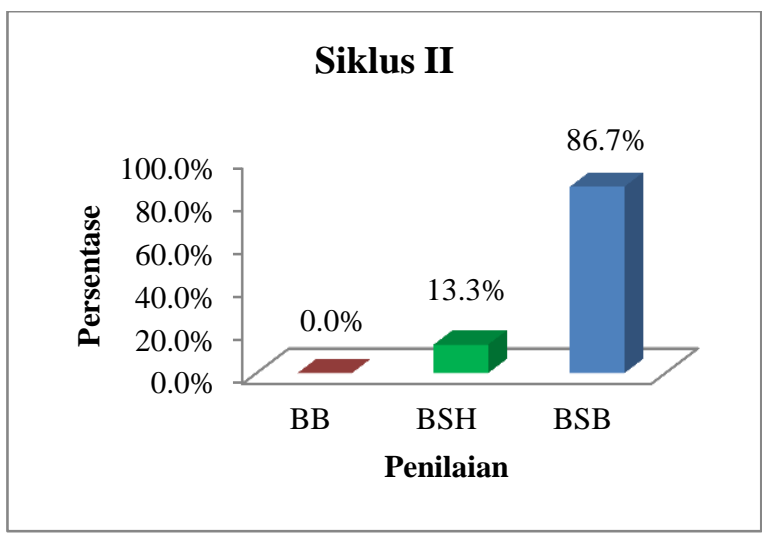

Grafik 3 Kreativitas Anak Siklus II

Berdasarkan data-data yang diperoleh selama kegiatan perbaikan pembelajaran dari kondisi awal sampai dengan Siklus II mengalami peningkatan yang sangat signifikan, pada Siklus II kemampuan yang dicapai sudah mencapai $86,7 \%$ yang dapat dikatakan baik dan mencapai indikator keberhasilan yang telah ditetapkan yaitu $80 \%$ anak mampu menunjukkan kreativitasnya.

Kreativitas anak pada Siklus II yaitu anak mampu menciptakan bentuk dan 
menceritakan hasil karyanya dengan bermain balok bangunan sudah mengalami peningkatan dibandingkan dengan pelaksanaan tindakan sebelumnya dalam mencapai indikator kemampuan ditetapkan. Oleh sebab itu pelaksanaan tindakan pada Siklus II ini dihentikan.

Berdasarkan dari hasil penelitian yang dilakukan oleh peneliti yang dilakukan selama enam kali tatap muka yang terbagi dalam dua siklus, menunjukkan bahwa kreativitas melalui kegiatan bermain balok bangunan pada anak mengalami peningkatan. Kegiatan peningkatan kreativitas yang sebelumnya hanya menggunakan metode ceramah dan gambar untuk menerangkan ke anak dan dilanjutkan dengan mengerjakan LKA tanpa diselingi dengan permainan, anakanak masih kesulitan dalam menciptakan bentuk suatu benda dan anak belum berani untuk menceritakan hasil karyanya. Dari hasil pengamatan yang telah dilakukan pada pratindakan, maka peneliti melalakukan tindakan dengan kegiatan bermain balok bangunan untuk meningkatkan kreativitas anak.

Implementasi dalam bermain balok bangunan, terlebih dahulu peneliti memberikan penjelasan dengan mempratikkan tata cara bermain balok bangunan. Hal tersebut diperkuat dalam teori Vygotsky (Santrock, 2002: 220) yang menyatakan bahwa anak-anak mengembangkan konsep yang salah satunya adalah konsep Scaffolding. Scaffolding adalah istilah terkait perkembangan kognitif yang digunakan Vygotsky untuk mendeskripsikan perubahan dukungan selama sesi pembelajaran, di mana orang yang lebih terampil mengubah bimbingan sesuai tingkat kemampuan anak.

Peningkatan kreativitas pada anak dapat dilihat dengan meningkatnya kemampuan anak saat menciptakan suatu bentuk dengan balok banguan dan menceritakan hasil karyanya. Adapun ketuntasan hasil belajar anak dari kondisi pra siklus sampai dengan Siklus II dapat dilihat pada tabel berikut :

\begin{tabular}{|c|c|c|c|c|c|c|c|}
\hline \multirow[t]{3}{*}{$\begin{array}{l}\mathrm{N} \\
\mathrm{o}\end{array}$} & \multirow{3}{*}{$\begin{array}{c}\text { Ketunta } \\
\text { san } \\
\text { Hasil } \\
\text { Belajar }\end{array}$} & \multicolumn{2}{|c|}{$\begin{array}{c}\text { Prasiklu } \\
\mathrm{s}\end{array}$} & \multicolumn{2}{|c|}{ Siklus I } & \multicolumn{2}{|c|}{$\begin{array}{c}\text { Siklus } \\
\text { II }\end{array}$} \\
\hline & & $\mathbf{J}$ & $\%$ & $\mathrm{~J}$ & $\%$ & $\mathbf{J}$ & $\%$ \\
\hline & & $\mathrm{ml}$ & & $\mathrm{ml}$ & & $\mathrm{ml}$ & \\
\hline 1 & $\mathrm{RSR}$ & 2 & $\begin{array}{c}13, \\
3\end{array}$ & 4 & $\begin{array}{c}26 \\
7\end{array}$ & 13 & $\begin{array}{c}86, \\
7\end{array}$ \\
\hline 2 & BSH & 2 & $\begin{array}{c}13, \\
3\end{array}$ & 4 & $\begin{array}{c}26 \\
7\end{array}$ & 2 & $\begin{array}{c}13, \\
3\end{array}$ \\
\hline 3 & BB & 11 & $\begin{array}{c}73, \\
4\end{array}$ & 7 & $\begin{array}{c}46 \\
6\end{array}$ & 0 & 0 \\
\hline
\end{tabular}




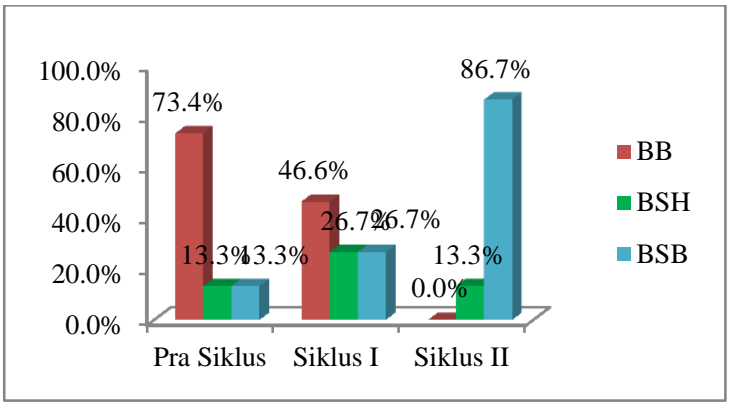

Grafik 4 Peningkatan Kreativitas Anak

Dari hasil penelitian di atas dapat terlihat bahwa untuk meningkatkan kreativitas anak dapat dilakukan melalui praktik langsung bermain balok bangunan. Kreativitas anak ditunjukkan dengan kemampuan anak dalam menciptakan suatu bentuk dengan menggunakan balok bangunan dan menceritakan hasil karyanya. Pada indikator kinerja peneliti menentukan $80 \%$ anak dapat menunjukkan kreativitasnya, pada Siklus II telah melebihi target yang diharapkan yaitu $86,7 \%$ anak mampu menunjukkan kreativitasnya dalam menciptakan suatu bentuk dengan menggunakan balok bangunan dan menceritakan hasil karyanya.

Penelitian ini sesuai dengan teori yang dikemukakan Piaget (Santrock, 2002:124), menjelaskan bahwa anak usia TK berada pada fase praoperasional, salah satu aspek perkembangan berpikirnya adalah berpikir intuitif. Berpikir intuitif merupakan fase berpikir dalam kemampuan untuk menciptakan sesuatu, berpikir secara kreatif seperti menggambar, menyusun balok, membentuk sesuatu benda yang menarik melalui benda-benda yang ada di sekitarnya.

\section{SIMPULAN}

Berdasarkan hasil penelitian dan pembahasan pada bab sebelumnya, dapat disimpulkan bahwa bermain balok bangunan terbukti efektif dapat meningkatkan kreativitas anak di Kelompok A TK Negeri Kabupaten Temanggung Tahun Pelajaran 2016/2017. Hal tersebut ditandai dengan tercapainya kriteria ketuntasan pada penelitian tindakan kelas yang sudah dilakukan. Kreativitas anak Kelompok A TK Negeri Kabupaten Temanggung dari kondisi awal sampai dengan dilaksanakannya perbaikan pembelajaran sampai dengan Siklus II telah mengalami peningkatan yang sangat signifikan.

Langkah penerapan praktik langsung bermain balok bangunan untuk meningkatkan kreativitas anak yaitu peneliti memberikan penjelasan dengan memberikan contoh secara langsung kepada anak mengenai cara-cara bermain balok bangunan. Kelas dibagi menjadi beberapa kelompok yang terdiri dari kelompok besar dan kelompok kecil. Peneliti memberikan tugas kepada masing- 
masing kelompok. Kelompok besar melakukan kegiatan meronce, menempel, menggambar dan mewarnai, sedangkan kelompok kecil mengerjakan kegiatan praktik langsung bermain balok bangunan. Setelah kegiatan di masing-masing kelompok selesai, anak-anak bertukar tempat dan bertukar kegiatan. Setelah bermain balok bangunan kegiatan selanjutnya adalah anak menjawab beberapa pertanyaan dan dilanjutkan dengan mengerjakan LKA dan bercerita mengenai bentuk yang dibuat anak setelah selesai menyusun balok bangunan menjadi suatu benda.

Ketuntasan hasil belajar anak yang mendapat nilai berkembang sangat baik dari Siklus I ke Siklus II mengalami kenaikan sebesar $60 \%$, sehingga dari kondisi awal ke Siklus II mengalami kenaikan sebesar 73,3\%. Berdasarkan hasil penelitian yang telah dilaksanakan terbukti bahwa melalui praktik langsung bermain balok bangunan dapat meningkatkan kreativitas anak Kelompok A TK Negeri Kabupaten Temanggung Tahun Pelajaran 2016/2017.

\section{DAFTAR PUSTAKA}

Adnan, Ismail. (2009). Education Game. Yogyakarta : Pro U Media.

Akbar, Sa'dun. (2010). Penelitian Tindakan Kelas. Yogyakarta: CV. Cipta Media.

Arikunto, Suharsimi. (2007). Penelitian Tindakan Kelas. Jakarta: Bumi Aksara.

Danar, Santi. (2009). Pendidikan Anak Usia Dini (Antara Teori dan Praktik). Jakarta: PT Mancana Jaya Cemerlang.

Haury, David L \& Peter Rillero. (1994). Perspectives of Hands On Science Teaching. Columbus : The ERIC Clearinghouse for Science.

Latif, Mukhtar. (2013). Orientasi Baru Pendidikan Anak Usia Dini. Jakarta : Kencana Media Group.

Mansur. (2007). Pendidikan Anak Usia Dini dalam Islam. Yogyakarta : Pustaka Pelajar.

Mayke S. Tedjasaputra. (2001). Bermain, Mainan, dan Permainan. Jakarta: PT. Grasindo.

Montolalu, BEF. (2009). Bermain dan Permainan Anak. Jakarta : Universitas Terbuka.

Mulyadi, S. (2004). Bermain dan Kreativitas (Upaya Mengembangkan Kreativitas Anak Melalui Kegiatan Bermain). Jakarta Papas Sinar Sinanti.

Munandar, Utami. (2009). Pengembangan Kreativitas Anak Berbakat. Jakarta : Rineka Cipta. 
Musbikin, Imam. (2007). Mendidik Anak Kreatif Ala Eistein. Yogyakara : Mitra Pustaka.

Nursisto. (1999). Kiat Menggali Kreativitas. Yogyakarta : Mitra Gama Widya.

Pamadhi, Hajar dan Evan Sukadi. (2011). Seni Ketrampilan Anak. Jakarta : Univeritas Terbuka.

Pramesti, Dian. (2007). Peningkatan Aktivitas dan Kreativitas Anak dalam Belajar. Jakarta : Rineka Cipta.

Rahmawati, Yeni. (2005). Strategi Pengembangan Kreativitas pada Anak Usia TK. Yogyakarta : Panduan Jala Sutra.

Rianto, T dan Handoko M. (2004). Pendidikan Anak Usia Dini. Jakarta : PT. Gramedia.

Sanjaya, Wina. (2011). Penelitian Tindakan Kelas. Jakarta: Kencana Prenada Media Group.

Santrock, John W. (2002). Perkembangan Anak (Child Development). Jakarta : Erlangga, MgGraw Hill, Inc.

Sudono, Anggraini. (2005). Permainan Kreatif. Jakarta : PM Pustaka.

Sugiyono. (2009). Metode Penelitian Pendidikan Pendekatan Kuantitatif, Kualitatif, dan $R \& D$. Bandung : Alfabeta.

Suhardjono. (2006). Prosedur Penelitian. Jakarta : Rineka Cipta.

Sujiono, Bambang. (2010). Bermain Kreatif Berbasis Kecerdasan Jamak. Jakarta : Indeks.
Suratno. (2005). Pengembangan Kreativitas Anak Usia Dini. Jakarta : Depdiknas.

Suwandi, Sawarji. (2009). Buku Ajar Penelitian Tindakan Kelas dan Penulisan Karya Ilmiah. Surakarta : Panitia Sertifikasi Guru Rayon 13 FKIP UNS.

Undang-undang Nomor 20 Tahun 2003 tentang Sistem Pendidikan Nasional. 